\title{
brazilianpoliticalsciencereview
}

RESEARCH NOTE

\section{The Victory of Jair Bolsonaro According to the Brazilian Electoral Study of 2018*}

\author{
Oswaldo E. do Amaral ${ }^{1}$ \\ https://orcid.org/0000-0002-9730-3619 \\ 1Universidade Estadual de Campinas, São Paulo/SP, Brazil
}

The 2018 elections surprised most analysts and political scientists in Brazil and abroad. The competitive dynamic that opposed the PT and the PSDB in presidential elections since 1994 has been disrupted, resulting in a novelty for the Brazilian party system. The purpose of this research article is to identify the determinants of votes for Jair Bolsonaro in the two rounds of the 2018 presidential election from data collected by the Brazilian Electoral Study. By means of multivariate analyses of the two rounds of the presidential election, we found that flourishing 'antipetismo' (i.e. anti-Workers' Party sentiment), growing numbers of voters self-identifying as right wing and increased importance of variables linked to voters' political identification all underpinned the victory of Jair Bolsonaro.

Keywords: Brazil elections; electoral behavior; political parties; Jair Bolsonaro; Eseb 2018.

http://doi.org/10.1590/1981-3821202000010004

Correspondence: Oswaldo E. do Amaral. E-mail: oswamaral@gmail.com This publication is registered under a CC-BY Licence.

* The author wished to thank the BPSR reviewers for their criticisms and comments and the CNPq for its funding (307503/2018-8). 
The 2018 elections surprised most analysts and political scientists in Brazil and abroad. The biggest prize, the Presidency of the Republic, was won by a Congressional Deputy with a modest career record: retired army captain Jair Bolsonaro, who headed a coalition comprising two low-profile conservative parties, the Social Liberal Party (PSL) and the Brazilian Labor Renewal Party (PRTB).

The 2018 election may represent a watershed for the Brazilian party system, by having broken the competitive logic that had set the Workers' Party (PT) against the Brazilian Social Democracy Party (PSDB) in presidential disputes since 1994. The purpose of this research article is to present and discuss the determinants of votes for Bolsonaro in 2018 with reference to data collected by the Brazilian Electoral Study (Eseb) and to point out some possible routes for future analyses.

The selection of variables that we analyzed was based on similar studies of the last four Brazilian presidential elections, such as those by Amaral and Ribeiro (2015), Bohn (2007), Carreirão (2007a, 2007b, 2002), Nicolau (2014, 2007), Peixoto and Rennó (2011), Ribeiro, Carreirão and Borba (2016, 2011), Samuels and Zucco (2018) and Zucco (2013). The text shows strong growth in antipetismo and the number of voters considered to be right wing, as well as the importance for Bolsonaro's victory of variables linked to the political identification of voters.

\section{The 2018 Eseb and votes for Jair Bolsonaro}

The Eseb 2018 was conducted by the Center for Public Opinion Studies (Cesop) of the State University of Campinas (Unicamp). In 2018, the Eseb was nationally sampled and interviews were conducted of 2506 voters in 172 cities across the country, including all state capitals. The survey was held shortly after the elections, between November 10 and 24, with home interviews. Its margin of error is two percentage points and the confidence index is $95 \%{ }^{1}$.

For the analysis in this research article, dependent variables were constructed by including voters who declared that they voted for Jair Bolsonaro

${ }^{1}$ The 2018 Eseb was carried out with Fapesp financing (2018/02738-0). 
(PSL), Fernando Haddad (PT) and Ciro Gomes of the Democratic Labor Party (PDT) in the first round (1588 cases), and Jair Bolsonaro and Fernando Haddad in the second round (1734 cases). Interviewees who did not vote, who voted for other candidates, who casted blank votes or annulled their ballots, or who did not remember or did not want to answer the question were excluded. The selection of the three candidates was due to the fact that they accounted for $87.8 \%$ of valid votes and only a low number of respondents indicated that they had voted for other candidates. A substantial number of lost cases occurred because about $20 \%$ of respondents said they did not vote or did not answer the question.

The explanatory variables were aggregated into two blocks according to the literature on electoral behavior in Brazil. The first block consisted of variables related to retrospective evaluations (Evaluation of the Government; Economic Status; Personal Economic Status; Being a beneficiary of the Bolsa Família Program (BFP); Evaluation of Politicians). The second block of variables were linked to political identification (Party Identification; Negative Party Identification; Ideological Self-Placement). In addition to these two blocks, sociodemographic variables and a contextual variable were included in the analysis.

Retrospective evaluation of government performance, especially in the economic arena, is a classic approach to electoral behavior, as attested by the work of Downs (1999), Key (1966) and Fiorina (1981), among others. As Rennó (2007) points out, votes based on a retrospective evaluation can be multidimensional, that is, they can take into account various aspects of government actions, not just issues related exclusively to the economy. Thus, the very idea of retrospective voting brings us closer to the possibility of vertical accountability, that is, the ability to punish or reward representatives according to the evaluation of their performance.

The relationship between political identification and electoral behavior has a long history in political science. Both authors linked to the Michigan School (CAMPBELL et al., 1960; CONVERSE, 1964) and those of the Rational Choice persuasion (DOWNS, 1999; FIORINA, 1981), in spite of differing assumptions, have pointed out the importance of political identification, especially party identification, in voter decisions. 
The contextual variable inserted in the model was Region. The choice of this variable was due to the fact that authors found a positive effect in multivariate analysis between voters in the Northeast region and Dilma Rousseff's candidacy in both the 2010 and 2014 elections (AMARAL and RIBEIRO, 2015; NICOLAU, 2014).

\section{Results and discussion}

The analysis of the vote in the first round was made by multinomial logistic regressions. As mentioned, those who voted for Ciro Gomes, Jair Bolsonaro and Fernando Haddad were compared, with the last group being members of the reference category. For the second round, the technique we used was binomial logistic regression. Thus, Bolsonaro voters were compared Haddad voters, again members of the reference category. For both rounds, three different tests were performed to better understand the impact of the selected variables. The first involved retrospective evaluation variables, the second, political identification variables and the third (the general model) included both blocks. In all of them, sociodemographic and contextual variables were present.

The results show that the six models were statistically significant. However, some important differences between them should be highlighted. In both the first and second rounds, the political identification models presented more robust results than those that included retrospective evaluation, including explanatory capacity close to the general models. In other words, the impact of these variables was stronger than that of the retrospective evaluation variables to explain votes in the 2018 presidential election ${ }^{2}$. In this article we will discuss the results of the general models only.

Individually, regarding retrospective evaluation, we found consistent effects on three variables in both rounds. Evaluating the Temer Government as great/good and average, compared to those who evaluated it as bad/terrible, increased chances of voting for Bolsonaro rather than Haddad. Evaluating the country's economic situation as equal or better than in the previous 12 months

\footnotetext{
${ }^{2}$ The model including only the retrospective evaluation variables had an R2 Nagelkerke of $.269(p<.001)$ in the first round and of .204 $(p<.001)$ in the second round. The model including the political identification variables had a R2 Nagelkerke of .512 $(p<.001)$ in the first round and of $.539(\mathrm{p}<.001)$ in the second round.
} 
increased the chance of voting for Ciro Gomes. Having risen in the class hierarchy in the previous eight years and being a beneficiary of the Bolsa Família Program (BFP) increased the chance of a vote for Haddad rather than Bolsonaro in both rounds, even though the effects are not high (Tables 01 and 02).

The perception of having ascended a class and the link with the BFP were clearly distinguishing factors between Haddad voters and Bolsonaro voters in both rounds. Haddad was rewarded for the redistributive policies implemented during the PT governments. This is an important finding because it shows - albeit preliminarily, since the PT administration had not been out of power for long and not as the result of an election - that voters linked the BFP and the improvement in their economic conditions during the last eight years of PT governments.

The variables related to political identification were all important predictors of voting in the 2018 presidential election, some with strong results. This finding is in line with what Borges and Vidigal (2018) found for in respect of presidential elections between 2002 and 2014. However, when the data for 2018 is examined more closely, a few novel aspects appear.

The first of these concerns the distribution of party preferences. Between 2002 and 2014, the most frequently cited parties were the PT and the PSDB. In $2014,18 \%$ said they liked the former, while 7\% said they liked the latter (RIBEIRO et al., 2016, p. 615). By 2018, the scenario had changed: $10 \%$ of respondents said, in a spontaneous question, that the PT was the group they felt closest to, while $6 \%$ mentioned the PSL. The PSDB was only mentioned in 01\% of responses.

The phenomenon of the growth of the PSL is not exactly new. According to the 2010 Eseb, for example, 03\% of respondents said they liked the Green Party (PV) of then presidential candidate Marina Silva. In subsequent years, however, this association failed to maintain the same level of preference. In regard to the PSL, it is very difficult to make any predictions about what lies ahead for it as Bolsonaro and many of his supporters left the party in November 2019 after an internal dispute. However, the party retains a considerable amount of public resources with which to compete in future elections.

Regarding the PT, the decrease in preference had also been verified between 2010 and 2014 (RIBEIRO et al., 2016; SAMUELS and ZUCCO, 2018). Repeated corruption scandals, President Dilma Rousseff's impeachment and an 
acute economic crisis certainly contributed to this result, indicating that some groups of supporters may be more susceptible to short-term stimuli and may therefore alter their preferences, as Samuels and Zucco argue $(2018$, p. 102). In short, in 2018, the PT had a significantly smaller stock of votes to count on than in the previous four presidential elections.

The results of the multivariate analyses show that, as in previous elections, party identification remains one of the strongest predictors of votes in Brazil. Identification with the PT, in both rounds, increased the chance of voting for Haddad rather than Bolsonaro by more than nine times, with the reference category being those who did not prefer any party. Similarly, identification with the PSL increased the chance of voting for Bolsonaro by more than four times in the first round and by more than seven in the second (Tables 01 and 02).

The second novelty concerns the rise of antipetismo. In 2014, antipetistas (anti-PT voters) outnumbered petistas (pro-PT voters) by about four percentage points (21\% to 17\%) (SAMUELS and ZUCCO, 2018, p. 28); by 2018, the difference had risen to 17 percentage points (27\% to 10\%), which made antipetismo, comprising positive and negative feelings, the main party identity in Brazil. Just as the fall in identification with the PT resulted from short-term stimuli, so, probably, did the rise in antipetismo, which was further favored by a highly polarized campaign to 'activate' the memories of negative experiences of the party in Federal Government.

Rejection of the PT also proved to be a strong predictor of vote. A voter who rejected the PT in both rounds was ten times more likely to vote for Bolsonaro than a voter who did not reject any party. As Ribeiro, Carreirão and Borba (2016) and Samuels and Zucco (2018) have already demonstrated, negative party identity in Brazil, as in other democratic contexts, can determine voter choices. The differences in 2018's antipetismo lie in its extent and in the presence of an actor Jair Bolsonaro - who managed to present himself as the party's main opponent, thus usurping the traditional role of the PSDB in recent presidential disputes. 
Table 01. Multinomial logistic regression. Vote for the president in the first round of presidential election (2018)

\begin{tabular}{|c|c|c|c|c|}
\hline \multirow[b]{2}{*}{ Evaluation of government (bad/terrible) } & \multicolumn{2}{|c|}{ Ciro Gomes } & \multicolumn{2}{|c|}{ Jair Bolsonaro } \\
\hline & $\mathrm{B}$ & $B(\operatorname{Exp})$ & $\mathrm{B}$ & $B(\operatorname{Exp})$ \\
\hline Great/Good & .278 & 1.320 & .685 & $1.984^{*}$ \\
\hline Average & .441 & 1.554 & 1.073 & $2.923^{*}$ \\
\hline \multicolumn{5}{|c|}{ Economic situation (much worse/somewhat worse) } \\
\hline Much/somewhat better & .675 & $1.964^{*}$ & .307 & 1.359 \\
\hline \multicolumn{5}{|c|}{ Personal economic situation (not improved/worsened) } \\
\hline Gone down a class & .126 & 1.134 & .201 & 1.222 \\
\hline Moved up a class & .028 & 1.028 & -.447 & $.640^{*}$ \\
\hline \multicolumn{5}{|l|}{ Bolsa Família Program Beneficiary } \\
\hline Beneficiary & -.749 & $.473^{*}$ & -.710 & $.492 *$ \\
\hline \multicolumn{5}{|c|}{$\begin{array}{l}\text { Perception vis-à-vis politicians being Brazil's main problem } \\
\text { (somewhat/strongly agrees) }\end{array}$} \\
\hline Disagrees somewhat/strongly & .128 & 1.137 & -.346 & .707 \\
\hline Does not agree/disagrees & -.238 & .788 & -.264 & .768 \\
\hline \multicolumn{5}{|l|}{ Party identification (none) } \\
\hline Others & .578 & 1.782 & -.008 & .992 \\
\hline PT & -.870 & $.419 *$ & -2.246 & $.106^{*}$ \\
\hline PSL & -.080 & .923 & 1.510 & $4,528^{*}$ \\
\hline \multicolumn{5}{|l|}{ Negative party identification (none) } \\
\hline Others & .536 & $1.709 *$ & -.580 & $.560 *$ \\
\hline PT & 1.656 & $5.240^{*}$ & 2.436 & $11,432 *$ \\
\hline \multicolumn{5}{|l|}{ Ideological self-identification (right) } \\
\hline Doesn't know & .954 & $2.596^{*}$ & -.099 & .905 \\
\hline Left & .954 & $2.596^{*}$ & -1.034 & $.356^{*}$ \\
\hline Center & 1.279 & $3.593^{*}$ & -.450 & $.638^{*}$ \\
\hline \multicolumn{5}{|l|}{ Region (Southeast) } \\
\hline North & -.423 & .655 & .106 & 1.112 \\
\hline Northeast & .027 & 1.027 & -.872 & $.418^{*}$ \\
\hline South & -.589 & .555 & -.180 & .835 \\
\hline Center-West & -.628 & .534 & -.119 & .888 \\
\hline \multicolumn{5}{|l|}{ Color (non-white) } \\
\hline White & .266 & 1.305 & .324 & 1.383 \\
\hline \multicolumn{5}{|l|}{ Religion (Catholic) } \\
\hline Others/None & .111 & 1.117 & .089 & 1.093 \\
\hline Pentecostal & -.172 & .842 & .839 & $2.314^{*}$ \\
\hline \multicolumn{5}{|l|}{ Sex } \\
\hline Male & -.097 & .907 & .560 & $1.750^{*}$ \\
\hline Education level & .242 & $1.274^{*}$ & .089 & $1.093^{*}$ \\
\hline Age & -.010 & .990 & .001 & 1.001 \\
\hline
\end{tabular}

Source: ESEB 2018.

Note: NB: N = 1411; Pseudo R2 (Nagelkerke) = .547; Log pseudolikelihood = 1825.710. ${ }^{*}(\mathrm{p}<0.05)$. The reference category was the vote for Fernando Haddad. The reference categories of each variable appear in parentheses. Education (with ten categories) and age were used continuously. 
Table 02. Binomial logistic regression. Vote for the president in the second round of presidential election (2018)

\begin{tabular}{|c|c|c|}
\hline & Jair Bol & \\
\hline & $\mathrm{B}$ & $\operatorname{Exp}(B)$ \\
\hline \multicolumn{3}{|c|}{ Assessment of government (bad/terrible) } \\
\hline Great/Good & .667 & $1.949^{*}$ \\
\hline Average & .891 & $2.437^{*}$ \\
\hline \multicolumn{3}{|c|}{ Economic situation (much worse/somewhat worse) } \\
\hline Much/somewhat better & .177 & 1.194 \\
\hline Unchanged & .158 & 1.171 \\
\hline \multicolumn{3}{|c|}{ Personal economic situation (not improved/worsened) } \\
\hline Gone down a class & .101 & 1.106 \\
\hline Moved up a class & -.442 & $.643^{*}$ \\
\hline \multicolumn{3}{|c|}{ Bolsa Família Program Beneficiary } \\
\hline Beneficiary & -.553 & $.575^{*}$ \\
\hline \multicolumn{3}{|c|}{$\begin{array}{l}\text { Perception that politicians are Brazil's main problem } \\
\text { (agrees somewhat/strongly) }\end{array}$} \\
\hline Disagrees somewhat/strongly & -289 & .749 \\
\hline Does not agree/disagrees & .112 & 1.118 \\
\hline \multicolumn{3}{|l|}{ Party identification (none) } \\
\hline Others & -.324 & .723 \\
\hline PT & -2.498 & $.082^{*}$ \\
\hline PSL & 1.965 & $7,132 *$ \\
\hline \multicolumn{3}{|c|}{ Negative party identification (none) } \\
\hline Others & -.516 & $.597^{*}$ \\
\hline PT & 2.373 & $10.729^{*}$ \\
\hline \multicolumn{3}{|c|}{ Ideological self-identification (right) } \\
\hline Doesn't know & -.416 & .659 \\
\hline Left & -1.252 & $.286^{*}$ \\
\hline Center & -.628 & $.533^{*}$ \\
\hline \multicolumn{3}{|l|}{ Region (Southeast) } \\
\hline North & .264 & 1.303 \\
\hline Northeast & -.694 & $.500^{*}$ \\
\hline South & .120 & 1.127 \\
\hline Center-West & .472 & 1.603 \\
\hline \multicolumn{3}{|l|}{ Color (non-white) } \\
\hline White & .106 & 1.112 \\
\hline \multicolumn{3}{|l|}{ Religion (Catholic) } \\
\hline Others/None & -.047 & .954 \\
\hline Pentecostal & .716 & $2.046^{*}$ \\
\hline \multicolumn{3}{|l|}{ Sex } \\
\hline Male & .497 & $1.644^{*}$ \\
\hline Education level & .082 & $1.085^{*}$ \\
\hline Age & .012 & $1.012^{*}$ \\
\hline
\end{tabular}

Source: ESEB 2018.

Note: NB: $\mathrm{N}=1542$; Pseudo R2 (Nagelkerke) $=.559 ;$ Log pseudolikelihood $=1258.444 .^{*}(\mathrm{p}<0.05)$. The reference category was the vote for Fernando Haddad. The reference categories of each variable appear in parentheses. Education (with ten categories) and age were used continuously.

The third novelty regarding political identification variables is linked to the distribution of voters along the left-right spectrum. As can be seen in Graph 01, respondents who positioned themselves on the right jumped from $27 \%$ in 2014 to $43 \%$ in 2018 . Those who positioned themselves on the left went from $08 \%$ to $15 \%$. 
Conversely, those who did not know what left and right were or could not position themselves on the spectrum dropped from $41 \%$ to $18 \%$.

Regarding multivariate analysis, it is possible to observe that ideological self-placement was a good predictor of the presidential vote in 2018. Being on the right increased the chances of choosing Bolsonaro over those on the left and center in both rounds. The stronger correlation with ideological self-placement seen in 2018 relative to previous elections may also be linked to ideological polarization. According to Zechmeister (2015), the more polarized the political system and the greater the use of ideological positioning by political elites, the greater the chances of a correlation between voter ideological self-placement and choice in presidential disputes.

Graph 01. Ideological self-placement 2006-2018 (\%)

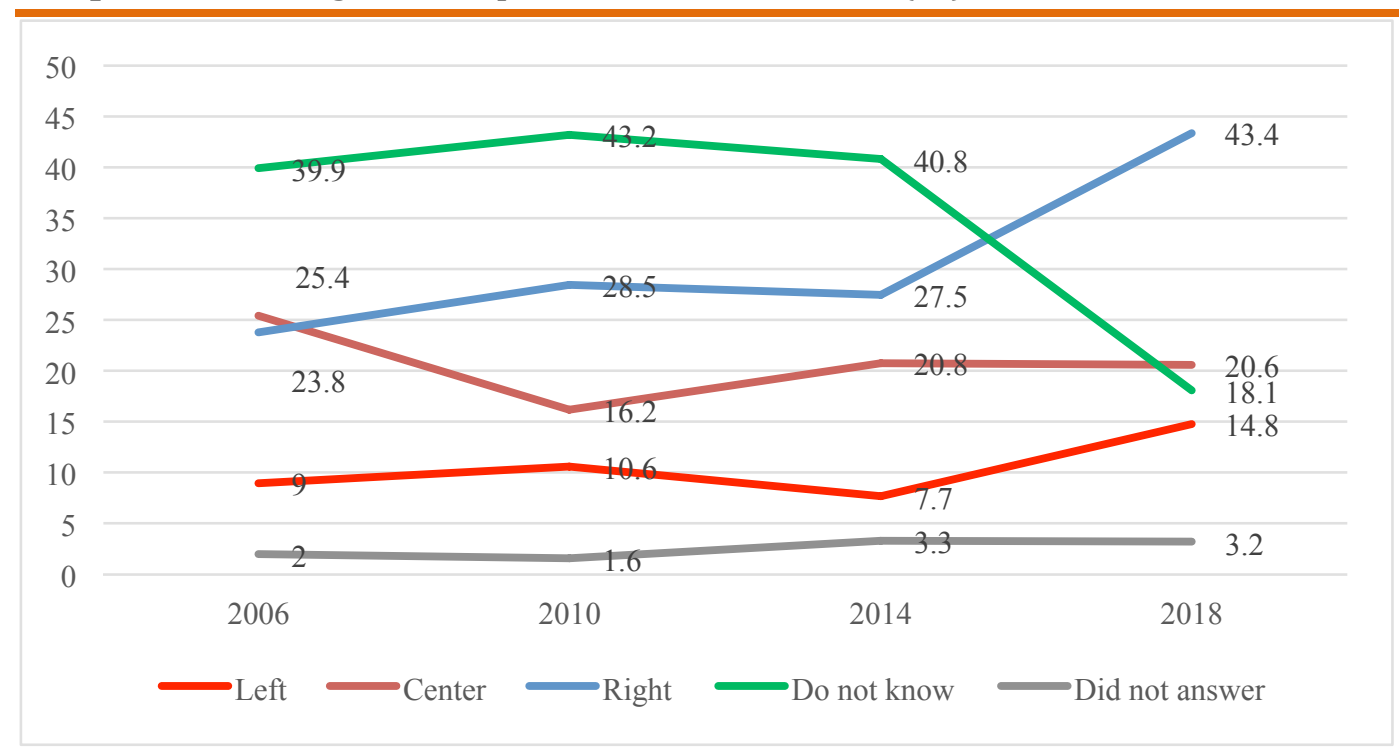

Source: ESEB, 2006; ESEB, 2010; ESEB, 2014; ESEB, 2018.

As in 2010 and 2014, the region in which the voter resides proved to be a relevant variable in understanding Brazilian electoral behavior. Residence in the Northeast reduced the chances of voting for Bolsonaro in both rounds relative to voters living in the Southeast. Identifying the reasons for this contextual effect is beyond the scope of this article. However, two lines of interpretation may be suggested. The first concerns the possibility of a reward from a retrospective evaluation of public policies for the Northeast region implemented during PT governments (AMARAL and RIBEIRO, 2015). The second, more political in nature, 
may be linked to alliances built in the region involving elections for state governments (LIMONGI and GUARNIERI, 2015).

Among the sociodemographic variables, as in the presidential elections of 2006 and 2010, Haddad was more likely to receive votes from among the least educated voters (NICOLAU, 2014; RENNÓ, 2007). The gender variable has never previously had an impact on presidential choices in Brazil. In 2018, however, in both rounds of the presidential race, the gender variable was statistically significant in multivariate analysis. Being male increased the chances of voting for Jair Bolsonaro as opposed to Ciro Gomes in the first round and Fernando Haddad in both rounds. Rather than a specific political cleavage, the results found for 2018 appear to be linked to Bolsonaro's own trajectory as a candidate. On more than one occasion, he has adopted aggressive rhetoric against women.

The variable Religion also presented statistically significant results. In both rounds, being a Pentecostal Christian rather than Catholic (the reference category) increased the odds of voting for Jair Bolsonaro. This is not a new phenomenon in Brazilian presidential elections. Bohn (2007; 2004) demonstrated that Anthony Garotinho (PSB), an openly Pentecostal candidate, mobilized this electorate in the 2002 dispute. In 2010 and 2014, it was the turn of Marina Silva, another openly Pentecostal candidate, to galvanize the support of part of this group around her candidacy (AMARAL and RIBEIRO, 2015; BOAS and SMITH, 2015; NICOLAU, 2014). The difference is that for the first time, a self-declared Catholic candidate was able to count on the support of Pentecostals, who, according to Eseb 2018, account for $31.8 \%$ of Brazilian voters.

In spite of his being Catholic, Bolsonaro has aligned himself with Pentecostal political and religious leaders due to their shared positioning vis-à-vis 'moral' issues. With an eye on the upcoming election, Bolsonaro had himself baptized in the Jordan River in 2016 by an important Pentecostal political leader, Pastor Everaldo. Finally, shortly before the first round of the presidential election, Bolsonaro received formal support from leaders of several Pentecostal churches, including Edir Macedo of the Universal Church of the Kingdom of God.

The data collected by Eseb 2018 show the strong growth of antipetismo and ideological self-placement on the right among Brazilian voters and the strong impact of political identification variables on voter choice. The choice of 
Pentecostals by a Catholic candidate was also a novelty and deserves better exploration in electoral studies. The 2018 election, according to Eseb data, was extremely adverse to any leftist candidacy. The candidate who was best able to articulate conservative positions with strong antipetismo in voters' minds was the winner.

Translated by Fraser Robinson

Submitted on March 19, 2019 Accepted on September 20, 2019

\section{References}

AMARAL, Oswaldo E. do and RIBEIRO, Pedro Floriano (2015), Por que Dilma de novo? Uma análise exploratória do Estudo Eleitoral Brasileiro de 2014. Revista de Sociologia e Política. Vol. 23, № 56, pp. 107-123.

BOAS, Taylor and SMITH, Amy Erica (2015), Religion and the Latin American voter. In: The Latin American voter: pursuing representation and accountability in challenging contexts. Edited by CARLIN, Ryan; SINGER, Matthew M., and ZECHMEISTER, Elizabeth J.. Ann Arbor: University of Michigan Press. pp. 99121.

BOHN, Simone R. (2007), Contexto político-eleitoral, minorias religiosas e voto em pleitos presidenciais (2002-2006). Opinião Pública. Vol. 13, № 02, pp. 366-387.

BOHN, Simone R. (2004), Evangélicos no Brasil: perfil socioeconômico, afinidades ideológicas e determinantes do comportamento eleitoral. Opinião Pública. Vol. 10 , № 02 , pp. 288-338.

BORGES, André and VIDIGAL, Robert (2018), Do lulismo ao antipetismo? Polarização, partidarismo e voto nas eleições presidenciais brasileiras. Opinião Pública. Vol. 24, № 01, pp. 53-89.

CAMPBELL, Angus; CONVERSE, Philip E.; MILLER, Warren E., and STOKES, Donald E. (1960), The American voter. Chicago: The University of Chicago Press. 576 pp..

CARREIRÃO, Yan de Souza (2007a), Identificação ideológica, partidos e voto na eleição presidencial de 2006. Opinião Pública. Vol. 13, № 02, pp. 307-339.

CARREIRÃO, Yan de Souza (2007b), A eleição presidencial brasileira de 2006: uma análise preliminar. Política \& Sociedade. Vol. 06, № 10, pp. 91-116.

CARREIRÃO, Yan de Souza (2002), A decisão do voto nas eleições presidenciais brasileiras. Rio de Janeiro: FGV Editora. 241 pp..

CONVERSE, Philip E. (1964), The nature of belief systems in mass publics. In: Ideology and its discontents. Edited by APTER, David E.. New York: The Free Press of Glencoe. pp. 206-261. 
DOWNS, Anthony (1999), Uma teoria econômica da democracia. São Paulo: Edusp. 334 pp..

ESEB 2018 (2018) Brazilian electoral survey 2018. Available at <http://www.cesop.unicamp.br>. Accessed on January, 15, 2019.

ESEB 2014 (2014), Brazilian Electoral Survey 2014. Available at $<h t t p: / / w w w . c e s o p . u n i c a m p . b r>$. Accessed on January, 15, 2019.

ESEB 2010 (2010), Brazilian Electoral Survey 2010. Available at <http://www.cesop.unicamp.br>. Accessed on January, 15, 2019.

ESEB 2006 (2006), Brazilian Electoral Survey 2006. Available at <http://www.cesop.unicamp.br>. Accessed on January, 15, 2019.

FIORINA, Morris P. (1981), Retrospective voting in American national elections. New Haven: Yale University Press. 249 pp..

KEY, Valdimer O. (1966), The responsible electorate: rationality in presidential voting, 1936-1966. Cambridge: The Belknap Press of Harvard University Press. 158 pp..

LIMONGI, Fernando and GUARNIERI, Fernando (2015), Competição partidária e voto nas eleições presidenciais no Brasil. Opinião Pública. Vol. 21, № 01, pp. 60-86.

NICOLAU, Jairo (2014), Determinantes do voto no primeiro turno das eleições presidenciais brasileiras de 2010: uma análise exploratória. Opinião Pública. Vol. 20, № 03, pp. 311-325.

NICOLAU, Jairo (2007), An analysis of the 2002 presidential elections using logistic regression. Brazilian Political Science Review. Vol. 01, № 01, pp. 125-135.

PEIXOTO, Vitor and RENNÓ, Lucio R. (2011), Mobilidade social ascendente e voto: as eleições presidenciais de 2010 no Brasil. Opinião Pública. Vol. 17, № 02, pp. 304-332.

RENNÓ, Lucio R. (2007), Escândalos e voto: as eleições presidenciais brasileiras de 2006. Opinião Pública. Vol. 13, № 02, pp. 260-282.

RIBEIRO, Ednaldo; CARREIRÃO, Yan, and BORBA, Julian (2016), Sentimentos partidários e antipetismo: condicionantes e covariantes. Opinião Pública. Vol. 22, № 03, pp. 603-637.

RIBEIRO, Ednaldo; CARREIRÃO, Yan, and BORBA, Julian (2011), Sentimentos partidários e atitudes políticas entre os brasileiros. Opinião Pública. Vol. 17, № 02, pp. 333-368. 
SAMUELS, David J. and ZUCCO, Cesar (2018), Partisans, antipartisans, and nonpartisans: voting behavior in Brazil. Cambridge: Cambridge University Press. 196 pp..

ZECHMEISTER, Elizabeth J. (2015), Left-right identifications and the Latin American voter. In: The Latin American voter: pursuing representation and accountability in challenging contexts. Edited by CARLIN, Ryan; SINGER, Matthew M., and ZECHMEISTER, Elizabeth J.. Ann Arbor: University of Michigan Press. pp. 195-225.

ZUCCO JR., Cesar (2013), When payouts pay off: conditional cash transfers and voting behavior in Brazil 2002-10. American Journal of Political Science. Vol. 57, № 04, pp. 810-822. 